\title{
Equity Price-Volume Relationship On The Russian Stock Exchange
}

Tov Assogbavi, (E-mail: tassogbavi@laurentian.ca), Laurentian University, Sudbury, Canada Jennifer Schell, Laurentian University, Sudbury, Canada

Siméon Fagnissè, Université de Parakou, Parakou, Rép. du Bénin

\begin{abstract}
This paper analyses the stock price-volume relationship of individual equities in the Russian Stock Exchange. Using a vector auto-regression analysis on weekly data, we present a strong evidence of bi-directional relationship between volume and price change. This finding confirms the evidence reported by studies on many developed markets. However, the weak support for the positive pricevolume relationship may imply that the differences in institutions and information flows in the Russian Stock Exchange might be important enough to affect the valuation process of their securities. Consequently, investors who based their investment strategies on momentum, have to adjust their strategies when trading on Russian Stock Markets.
\end{abstract}

\section{INTRODUCTION}

nvestors and academics alike have given considerable attention to the price-volume relationship over the past two decades. While many studies have attempted to establish the empirical and theoretical structure of this relationship, a consensus is yet to be reached. Given the divergent conclusions of this research, further insights should be obtained through investigations on alternative sets of financial markets. Emerging markets constitute good candidates for such an additional investigation into the price-volume relationship because of their differences in terms of structure and information flows. After studying this relationship on a set of emerging market indexes, attention is now turned to individual securities of some of these markets. There are theoretical models that hypothesize a stock price-volume relationship based on information flows and operational structure of market institutions (see, for example, Copeland, 1976 and Jennings et al., 1981). Given these hypotheses, an empirical study using alternative markets should provide new insights into this relationship at the individual level. By investigating a set of Latin American markets Saatcioglu and Starks (1998) find that there is a positive relation between volume and both the magnitude of price change and price change itself, and that there is no strong evidence on causality relation. Assogbavi and Osagie (2006) find strong evidence on stock price changes leading trading volume on selected emerging markets. Our objective in this paper is to investigate the price-volume relationship on major individual equities on the Russian Stock Exchange. As these equities are the major stocks in Russian fast growing markets, one would expect a price-volume behavior similar, to the one found in developed markets. The remainder of the paper is organized as follows: an overview of previous research on the relationship between price changes and volume is presented in Section II; the Russian Stock Exchange data used is described in section III; the methodology and the empirical results are presented in section IV; finally, our conclusions appear in Section V.

\section{LITTERATURE REVIEW}

The importance of the price-volume relationship has been first single out by Karpoff (1987) where he outlines the major reasons why the understanding of the relation between stock prices and volume is important. First, the empirical relation between returns and volume helps discriminate between competing theories on how information is disseminated in financial markets. Second, for event studies that use combinations of return and volume data to infer the information content of the event in question, the construction of the tests and the validity of the inferences depend on the joint distribution of returns and volume. Third, the return-volume relationship is critical in assessing the distribution of returns themselves. For example, the mixture of distributions hypothesis has been employed to view the 
distribution of price changes (i.e., returns) as a finite-variance mixture of normal distributions where volume is the mixing variable (e.g., Epps and Epps, 1976). Fourth, a better understanding of the statistical structure of volume and return can help explain technical analysis (see Blume et al, 1994). Beyond these rationales, the price-volume relation can also be used to validate two well-known Wall Street adages: (i) volume is relatively heavy in bull markets and light in bear markets, and (ii) it takes volume to make prices move.

Early empirical research on the stock price-volume relation in financial markets primarily focuses on two of the empirical relations implied by these adages: (i) the correlation between volume $(\mathrm{V})$ and price change $(\Delta \mathrm{P})$ and (ii) the correlation between volume $(\mathrm{V})$ and the absolute value of the price change $(\Delta \mathrm{P})$. A couple of early studies use spectral analysis on weekly index, daily and transactions individual stock data. Both studies conclude that prices and volume are virtually unrelated and that price changes follow a random walk (Granger and Morgenstern, 1963; Godfrey et al, 1964). In contrast, using daily and hourly price changes for both market indices and individual stocks Crouch (1970a) (1970b) finds a positive correlation between volume and the magnitude of returns. Examining the relation between volume and returns, a positive contemporaneous correlation has been found by Rogalski (1978) using monthly stock and warrant data and by Epps (1975), (1977) using transactions data. To explain such results, Epps proposes a theoretical framework consistent with his findings and supported by Smirlock and Starks (1985) and by Assogbavi et al. (1995), in the Canadian market. More recent empirical work has investigated the lagged relation between price changes and volume. For example, Smirlock and Starks (1988), employing individual stock transactions data, document a strong positive lagged relation between volume and absolute price changes. Similarly, using daily data, Bhagat and Bhatia (1996) test for causality in both mean and variance and provide evidence that price changes lead volume, but no evidence that volume leads price changes. In addition, Hiemstra and Jones (1995) find a new result through the use of nonlinear Granger causality. They find a significant positive relationship going in both directions between returns and volume. Few studies have examined the price-volume relationship in markets outside of the North American markets. Given this mix of findings, additional results from other financial markets are needed to better understand the price-volume relationship both at indexes and individual equities level. The Russian equity markets are good candidates for such a study. As these markets are becoming popular with institutional investors, it becomes necessary to investigate the price-volume relationship in these markets. The benefit of studying the Russian markets is twofold. First, it will allow improving the understanding of price-volume relationship and second, it can help to better comprehend the functioning of the Russian markets at the individual equity level.

\section{DATA AND ANALYSIS}

The data set used in this study come from the Russian Trading System (RTS) "Stock Exchange" The RTS was established in 1995 to consolidate separate regional securities trading floors into a unified regulated Russian securities market. The Exchange used to work on trading and settlement software supplied by NASDAQ. In 1998 the RTS switched from NASDAQ trading software to a more modern software and hardware system fully developed inhouse. The Russian Trading System lists leading Russian securities that are of great interest to both domestic and foreign portfolio investors, thus providing the industry with the most important market indicators. The individual equities used in this study are among the most active securities available in the RTS for at least three years. In total, 60 stocks were selected from various industries represented in the index. After controlling for data information availability, only 28 equities are retained for the study. They are obtained from RUSTOCKS.com. The data stretch from January 1997 to December 2005 and comprise weekly closing prices and trading volume. In our analysis, the trading volume is measured as the market turnover instead of the number of shares traded to avoid having to control for events such as stock splits, fights issues, and stock dividends. Table I provides summary statistics on each of the individual stocks for the sampling period. The statistical summaries of yearly returns of the individual stocks is calculated as $\ln \left(\mathrm{P}_{\mathrm{t}} / \mathrm{P}_{\mathrm{t}-1}\right)$ using the U.S. currency over the sampling period. One of the most striking features of these calculations is the low volatility as measured by the standard error. One would have expected a higher volatility on this market. 
Table 1: Sample Summary Statistics

This table provides descriptive statistics for the Russian stocks analyzed: Ticker Symbol; Weekly Returns, Standard Deviation; Standard Error; Skewness; Kurtosis, and Market Cap for 41 Russian individual equities over the period from January 1995 through to December 2005. Turnover is the percentage of total market capitalization traded in a given period. All summary statistics are for weekly data series.

\begin{tabular}{|c|c|c|c|c|c|c|c|}
\hline Company Name & $\begin{array}{c}\text { Weekly } \\
\text { Returns }\end{array}$ & $\begin{array}{c}\text { Std. } \\
\text { Deviation }\end{array}$ & $\begin{array}{l}\text { Standard } \\
\text { Error }\end{array}$ & Skewness & Kurtosis & \multicolumn{2}{|c|}{$\begin{array}{l}\text { Market } \\
\text { Cap. } 10^{6}\end{array}$} \\
\hline Aeroflot & 0.49 & 0.45 & 0.90 & 1.23 & 0.18 & $\$$ & 2,610 \\
\hline Severstal & 2.65 & 2.97 & 1.12 & 1.09 & -0.23 & $\$$ & 829 \\
\hline Unified Energy Sys. & 0.19 & 0.11 & 0.57 & 0.37 & -0.93 & $\$$ & 870 \\
\hline Sibirtelekom & 0.03 & 0.02 & 0.69 & 0.68 & -0.51 & $\$$ & 1,093 \\
\hline Center Telecom. & 82.78 & 110.39 & 1.34 & 1.58 & 2.53 & $\$$ & 1,007 \\
\hline Lenenergo & 0.45 & 0.28 & 0.62 & 0.47 & -0.91 & $\$$ & 383 \\
\hline Lukoil Oao & 18.33 & 11.34 & 0.62 & 1.55 & 2.72 & $\$$ & 77,869 \\
\hline Mosenergo & 0.07 & 0.04 & 0.63 & 0.80 & -0.31 & $\$$ & 4,944 \\
\hline Volga Telecom & 2.25 & 1.27 & 0.62 & 1.19 & 1.80 & $\$$ & 1,050 \\
\hline Purneftegaz & 7.38 & 8.86 & 1.20 & 2.12 & 3.85 & $\$$ & 5,304 \\
\hline Southern Telecom. & 0.12 & 0.07 & 0.67 & 2.30 & 5.24 & $\$$ & 480 \\
\hline Rostelecom & 1.91 & 1.03 & 0.54 & 0.84 & 0.19 & $\$$ & 2,569 \\
\hline Sberbank Of Russia & 228.37 & 246.09 & 1.09 & 1.79 & 3.51 & $\$$ & 2,949 \\
\hline Surgutneftegas & 0.36 & 0.25 & 0.67 & 1.03 & 0.21 & $\$$ & 63,414 \\
\hline North-West Telecom Ord & 0.66 & 0.48 & 0.73 & 2.06 & 4.43 & $\$$ & 1,084 \\
\hline Tatneft & 0.90 & 0.66 & 0.74 & 1.52 & 3.09 & $\$$ & 13 \\
\hline Uralsvyazinform & 0.03 & 0.02 & 0.68 & 1.12 & 1.13 & $\$$ & 284 \\
\hline Yukos & 4.20 & 4.41 & 1.04 & 0.91 & -0.53 & $\$$ & 1,901 \\
\hline Gaz Auto Plt. & 37.81 & 29.72 & 0.79 & 2.17 & 3.98 & $\$$ & 1,110 \\
\hline Irkutskenergo & 0.14 & 0.09 & 0.64 & 1.12 & 0.35 & $\$$ & 2,955 \\
\hline Kamaz & 0.58 & 0.70 & 1.21 & 3.02 & 9.79 & $\$$ & 1,218 \\
\hline Kuzbassenergo & 0.35 & 0.27 & 0.86 & 0.78 & -0.80 & $\$$ & 1,394 \\
\hline Moscow City Tel. & 7.79 & 5.09 & 0.65 & 0.40 & -0.22 & $\$$ & 292 \\
\hline Orenburgneft Pf & 7.62 & 10.99 & 1.39 & 1.87 & 2.62 & $\$$ & 17 \\
\hline Rostovenergo & 0.03 & 0.02 & 0.68 & 1.00 & 0.58 & $\$$ & 141 \\
\hline Sakhalinmorneftegaz & 4.00 & 2.79 & 0.70 & 1.42 & 2.37 & $\$$ & 71 \\
\hline Samaraenergo & 0.06 & 0.04 & 0.76 & 0.59 & -1.06 & $\$$ & 820 \\
\hline Slavneft Megionneftegaz & 8.84 & 9.92 & 1.12 & 1.73 & 2.87 & $\$$ & 6,068 \\
\hline
\end{tabular}

\section{EMPIRICAL RESULTS}

\section{Positive Relationship Tests}

The price volume-relationship is tested by investigating whether the two Wall Street adages: "volume is relatively heavy in bull markets and light in bear markets" and "it takes volume to make prices move" are relevant for individual Russian securities.

Following Karpoff (1987) the coefficients of the following two regression are estimated:

$V=\alpha_{0}+\alpha_{1} \ln \left(P_{t} / P_{t-1}\right)$.

$\mathrm{V}=\beta_{o}+\beta_{1}\left|\ln \left(\mathrm{P}_{\mathrm{t}} / \mathrm{P}_{\mathrm{t}-1}\right)\right|$.

where (V) is volume measured by weekly turnover, and the price change, the natural logarithm of the price relative for a given week. 
The results of equation (1) indicate that the contemporaneous correlation between weekly return and volume is significantly positive for only 11 of the 28 Russian individual equities in the sample.

\section{Table II: Asymmetry Test}

This table provides the coefficient estimates from regressions of volume against price changes (returns) for Russian individual equities over the period January 1995 through December 2005 (t-statistics are in parentheses). Eq (1) $\mathbf{V}=\boldsymbol{\alpha}_{\mathbf{0}}+\boldsymbol{\alpha}_{\mathbf{1}} \mathbf{l n}\left(\mathbf{P}_{\mathbf{t}} / \mathbf{P}_{\mathrm{t}-\mathbf{1}}\right)$

\begin{tabular}{|c|c|c|c|c|c|}
\hline Company & Observations & $\alpha_{0}$ & $\alpha_{1}$ & F-statistic & A.R-square \\
\hline Aeroflot & 338 & $\begin{array}{l}1343.193 \\
(12.432)\end{array}$ & $\begin{array}{c}0.034 \\
(0.623)\end{array}$ & 0.389 & -0.002 \\
\hline Severstal & 323 & $\begin{array}{l}213.328 \\
(16.663)\end{array}$ & $\begin{array}{c}0.156 \\
(2.827)\end{array}$ & 7.993 & 0.021 \\
\hline Unified Energy Sys. & 467 & $\begin{array}{c}192143.610 \\
(31.327)\end{array}$ & $\begin{array}{c}-0.005 \\
(-0.100)\end{array}$ & 0.100 & -0.002 \\
\hline Sibirtelekom & 292 & $\begin{array}{r}8471.289 \\
(14.058)\end{array}$ & $\begin{array}{c}0.138 \\
(2.371)\end{array}$ & 5.623 & 0.160 \\
\hline Central Telecom & 277 & $\begin{array}{c}486.449 \\
(9.706)\end{array}$ & $\begin{array}{c}0.032 \\
(0.539)\end{array}$ & 0.290 & -0.003 \\
\hline Lenenergo & 268 & $\begin{array}{c}379.923 \\
(7.839)\end{array}$ & $\begin{array}{c}0.125 \\
(2.064)\end{array}$ & 4.259 & 0.012 \\
\hline Lukoil & 467 & $\begin{array}{l}1466.372 \\
(24.462)\end{array}$ & $\begin{array}{c}-0.053 \\
(-1.135)\end{array}$ & 1.289 & 0.001 \\
\hline Mosonergo & 457 & $\begin{array}{c}101318.410 \\
(21.014)\end{array}$ & $\begin{array}{c}0.032 \\
(0.681)\end{array}$ & 0.464 & -0.001 \\
\hline Volga Telecom & 287 & $\begin{array}{l}115.269 \\
(14.596)\end{array}$ & $\begin{array}{c}0.143 \\
(2.446)\end{array}$ & 5.983 & 0.170 \\
\hline Purneftegaz & 244 & $\begin{array}{l}70.567 \\
(6.591)\end{array}$ & $\begin{array}{c}0.094 \\
(1.477)\end{array}$ & 2.183 & 0.005 \\
\hline Southern Telecom. & 338 & $\begin{array}{c}1882.453 \\
(12.184)\end{array}$ & $\begin{array}{c}0.181 \\
(3.380)\end{array}$ & 11.425 & 0.030 \\
\hline Rostelecom & 467 & $\begin{array}{c}2416.412 \\
(27.713)\end{array}$ & $\begin{array}{c}0.067 \\
(1.455)\end{array}$ & 2.118 & 0.002 \\
\hline Sberbank Of Russia & 435 & $\begin{array}{c}14.937 \\
(19.915)\end{array}$ & $\begin{array}{c}0.185 \\
(3.921)\end{array}$ & 15.373 & 0.032 \\
\hline Surgutneftegas & 467 & $\begin{array}{c}37777.35 \\
(21.723)\end{array}$ & $\begin{array}{c}0.137 \\
(2.993)\end{array}$ & 8.956 & 0.017 \\
\hline North-W Telelecom & 331 & $\begin{array}{l}341.457 \\
(10.970)\end{array}$ & $\begin{array}{c}0.170 \\
(3.133)\end{array}$ & 9.816 & 0.026 \\
\hline Tatfneft & 457 & $\begin{array}{c}5493.865 \\
(21.230)\end{array}$ & $\begin{array}{c}0.115 \\
(2.464)\end{array}$ & 6.070 & 0.011 \\
\hline Uralsvyazinform & 364 & $\begin{array}{c}17845.894 \\
(15.800)\end{array}$ & $\begin{array}{c}0.107 \\
(2.041)\end{array}$ & 4.167 & 0.009 \\
\hline Yukos & 346 & $\begin{array}{c}1313.570 \\
(15.593)\end{array}$ & $\begin{array}{c}0.070 \\
(1.298)\end{array}$ & 1.685 & 0.002 \\
\hline Gaz Auto PIt. & 339 & $\begin{array}{c}8.636 \\
(13.278)\end{array}$ & $\begin{array}{c}0.018 \\
(0.334)\end{array}$ & 0.111 & -0.003 \\
\hline Irkutskenergo & 416 & $\begin{array}{c}9112.867 \\
(10.141)\end{array}$ & $\begin{array}{c}0.059 \\
(1.214)\end{array}$ & 1.474 & 0.001 \\
\hline Kamaz & 268 & $\begin{array}{c}283.702 \\
(7.759)\end{array}$ & $\begin{array}{c}0.116 \\
(1.912)\end{array}$ & 3.657 & 0.010 \\
\hline Kuzbassenergo & 237 & $\begin{array}{c}521.000 \\
(9.360)\end{array}$ & $\begin{array}{c}0.094 \\
(1.445)\end{array}$ & 2.089 & 0.005 \\
\hline Moscow City Tel. & 268 & $\begin{array}{c}8366.430 \\
(3.903)\end{array}$ & $\begin{array}{c}0.003 \\
(0.048)\end{array}$ & 0.002 & -0.004 \\
\hline Orbenburgneft Pf. & 238 & $\begin{array}{l}23.161 \\
(5.972)\end{array}$ & $\begin{array}{c}-0.089 \\
(-1.375)\end{array}$ & 1.891 & 0.004 \\
\hline Rostovenergo & 172 & $\begin{array}{c}3226.443 \\
(8.523)\end{array}$ & $\begin{array}{c}0.140 \\
(1.850)\end{array}$ & 3.421 & 0.014 \\
\hline Sakhalinmorneftegaz & 200 & $\begin{array}{l}43.926 \\
(9.256)\end{array}$ & $\begin{array}{c}0.171 \\
(2.443)\end{array}$ & 5.967 & 0.240 \\
\hline Samaraenergo & 238 & $\begin{array}{c}5660.509 \\
(1.805)\end{array}$ & $\begin{array}{c}-0.087 \\
(-1.352)\end{array}$ & 1.828 & 0.003 \\
\hline Slavneft Megionneftegz & 319 & $\begin{array}{c}107.039 \\
(9.483) \\
\end{array}$ & $\begin{array}{c}0.083 \\
(1.149) \\
\end{array}$ & 2.232 & 0.004 \\
\hline
\end{tabular}


Table III: Positive Price-Volume

This table provides the coefficient estimates from regressions of volume against price changes (returns) Russian individual equities over the period January 1997 through December 2005 (t-statistics are in parentheses). Eq (2) $\mathbf{r} \mathbf{V}=\boldsymbol{\alpha}_{\mathbf{0}}+\boldsymbol{\alpha}_{\mathbf{1}}\left|\ln \left(\mathbf{P}_{\mathbf{t}} / \mathbf{P}_{\mathbf{t}-\mathbf{1}}\right)\right|$

\begin{tabular}{|c|c|c|c|c|c|}
\hline Company & Observations & $\alpha_{0}$ & $\alpha_{1}$ & F-statistic & A.R-square \\
\hline Aeroflot & 339 & $\begin{array}{c}1031.881 \\
(7.994)\end{array}$ & $\begin{array}{c}0.225 \\
(4.246)\end{array}$ & 18.027 & 0.048 \\
\hline Severstal & 323 & $\begin{array}{l}201.058 \\
(14.382)\end{array}$ & $\begin{array}{c}0.145 \\
(2.629)\end{array}$ & 6.913 & 0.018 \\
\hline Unified Energy Sys. & 467 & $\begin{array}{c}158315.130 \\
(21.535)\end{array}$ & $\begin{array}{c}0.327 \\
(7.474)\end{array}$ & 55.811 & 0.105 \\
\hline Sibirtelekom & 297 & $\begin{array}{c}8313.635 \\
(12.831)\end{array}$ & $\begin{array}{c}0.058 \\
(0.995)\end{array}$ & 0.989 & 0.000 \\
\hline Central Telecom & 278 & $\begin{array}{c}494.022 \\
(9.613)\end{array}$ & $\begin{array}{c}-0.052 \\
(-0.872)\end{array}$ & 0.760 & -0.001 \\
\hline Lenenergo & 268 & $\begin{array}{c}384.868 \\
(6.304)\end{array}$ & $\begin{array}{l}-0.007 \\
(-0.108)\end{array}$ & 0.012 & -0.004 \\
\hline Lukoil & 467 & $\begin{array}{c}1002.241 \\
(12.749)\end{array}$ & $\begin{array}{c}0.360 \\
(8.343)\end{array}$ & 69.602 & 0.128 \\
\hline Mosonergo & 457 & $\begin{array}{c}93795.141 \\
(17.107)\end{array}$ & $\begin{array}{c}0.131 \\
(2.815)\end{array}$ & 7.926 & 0.015 \\
\hline Volga Telecom & 288 & $\begin{array}{l}115.518 \\
(12.376)\end{array}$ & $\begin{array}{c}-0.011 \\
(-0.185)\end{array}$ & 0.034 & -0.003 \\
\hline Purneftegaz & 244 & $\begin{array}{l}70.853 \\
(5.573)\end{array}$ & $\begin{array}{c}0.007 \\
(0.102)\end{array}$ & 0.100 & -0.004 \\
\hline Southern Telecom. & 339 & $\begin{array}{c}1814.974 \\
(10.081)\end{array}$ & $\begin{array}{c}0.035 \\
(0.641)\end{array}$ & 0.411 & -0.002 \\
\hline Rostelecom & 467 & $\begin{array}{c}2168.968 \\
(18.706)\end{array}$ & $\begin{array}{c}0.147 \\
(3.202)\end{array}$ & 10.252 & 0.019 \\
\hline Sberbank Of Russia & 436 & $\begin{array}{c}13.104 \\
(13.778)\end{array}$ & $\begin{array}{c}0.163 \\
(3.453)\end{array}$ & 11.922 & 0.024 \\
\hline Surgutneftegas & 467 & $\begin{array}{c}25227.887 \\
(12.061)\end{array}$ & $\begin{array}{c}0.404 \\
(9.547)\end{array}$ & 91.150 & 0.162 \\
\hline North-West Telelecom & 331 & $\begin{array}{l}315.969 \\
(9.013)\end{array}$ & $\begin{array}{c}0.900 \\
(1.633)\end{array}$ & 2.666 & 0.005 \\
\hline Tatfneft & 457 & $\begin{array}{c}4530.429 \\
(13.303)\end{array}$ & $\begin{array}{c}0.201 \\
(4.389)\end{array}$ & 19.262 & 0.038 \\
\hline Uralsvyazinform & 365 & $\begin{array}{c}17802.802 \\
(14.627)\end{array}$ & $\begin{array}{c}0.000 \\
(0.002)\end{array}$ & 0.000 & -0.003 \\
\hline Yukos & 347 & $\begin{array}{l}1304.21 \\
(13.795)\end{array}$ & $\begin{array}{c}0.002 \\
(0.035)\end{array}$ & 0.001 & -0.003 \\
\hline Gaz Auto PIt. & 339 & $\begin{array}{c}6.990 \\
(8.307)\end{array}$ & $\begin{array}{c}0.163 \\
(3.031)\end{array}$ & 9.186 & 0.024 \\
\hline Irkutskenergo & 416 & $\begin{array}{c}7436.597 \\
(6.831)\end{array}$ & $\begin{array}{c}0.132 \\
(2.722)\end{array}$ & 7.407 & 0.015 \\
\hline Kamaz & 268 & $\begin{array}{c}270.223 \\
(6.209)\end{array}$ & $\begin{array}{c}0.035 \\
(0.565)\end{array}$ & 0.319 & -0.003 \\
\hline Kuzbassenergo & 238 & $\begin{array}{c}454.123 \\
(6.662)\end{array}$ & $\begin{array}{c}0.108 \\
(1.677)\end{array}$ & 2.812 & 0.008 \\
\hline Moscow City Tel. & 268 & $\begin{array}{c}8519.541 \\
(3.858)\end{array}$ & $\begin{array}{c}-0.018 \\
(-0.287)\end{array}$ & 3.858 & -0.003 \\
\hline Orbenburgneft Pf. & 239 & $\begin{array}{l}19.104 \\
(4.394)\end{array}$ & $\begin{array}{c}0.124 \\
(1.922)\end{array}$ & 3.693 & 0.011 \\
\hline Rostovenergo & 173 & $\begin{array}{c}3223.010 \\
(7.384)\end{array}$ & $\begin{array}{c}-0.001 \\
(-0.013)\end{array}$ & 0.000 & -0.006 \\
\hline Sakhalinmorneftegaz & 200 & $\begin{array}{l}42.559 \\
(7.421)\end{array}$ & $\begin{array}{c}0.043 \\
(0.607)\end{array}$ & 0.368 & -0.003 \\
\hline Samaraenergo & 238 & $\begin{array}{c}3631.852 \\
(0.980)\end{array}$ & $\begin{array}{c}0.066 \\
(1.014)\end{array}$ & 1.029 & 0.000 \\
\hline Slavneft Megionneftegz & 319 & $\begin{array}{l}104.97 \\
(7.832)\end{array}$ & $\begin{array}{c}0.022 \\
(0.395)\end{array}$ & 0.156 & -0.003 \\
\hline
\end{tabular}


This price-volume test that stands also for asymmetry test (trading volume following price increases is higher than that related to price decreases) indicates that for any given price change, the trading volume resulting from an increase in price is only $39 \%$ higher than the trading volume resulting from a decrease in price. This finding confirms the results of Assogbavi and Osagie (2006) that clearly indicate the absence of such asymmetric relationship in emerging markets. It shows that trading volume resulting from price increases is not statistically different from trading volume following price decreases. This finding does not lend support to the Wall Street adage: "volume is relatively heavy in bull markets and light in bear markets. While this empirical evidence does not support most of the US studies, it supports Karpoff (1986 and 1987) and Assogbavi et al. (1995) who relate the observed price-volume asymmetry in developed markets to the higher cost of short sales in relation to margin buying. As short sale trading is not popular, if permitted on Russian markets, the cost of taking a long position might not be different from that of taking a short position. If so, this will be consistent with our results. The results of equation (2) indicate that the contemporaneous positive relation between volume-absolute price-change holds only for 12 of the 28 equities.

This weak evidence of the contemporaneous positive correlation between absolute price-changes and volume might well be explained in Epps \& Epps (1976) and in Karpoff (1986). As Karpoff (1986) would have put it, investors in most of the Russian Exchange are late in the informational queue, preventing synchronization in pricechanges and trading volume for a given point in time. The information flow in these markets may well be disseminated sequentially instead of instantaneously as required in the Epps \& Epps model. In fact, following Epps \& Epps (1976), the justification of the presence of positive correlation between absolute price-change and volume comes from the fact that all investors receive information simultaneously. It is quite reasonable that this hypothesis might not hold in the Russian markets where it is conceivable that the information dissemination is likely to be sequential than simultaneous because of different operational structures of their markets.

\section{Granger Causality Tests}

The causality tests allow investors to know which variable causes the other. The tests are normally conducted by testing whether there is a relation between the lagged values of the two series. Consequently, to test whether volume leads return or return leads volume, we employ Granger causality tests, as has been done in previous research on developed markets (e.g., Smirlock and Starks, (1988), and Assogbavi et al. (1992). By controlling for any serial correlation in the dependent variable itself, the Granger causality regressions are as follows:

$\operatorname{Vol}_{\mathrm{t}}=\alpha_{\mathrm{o}}+\Sigma_{\mathrm{i}=1-12} \alpha_{\mathrm{i}} \operatorname{Vol}_{\mathrm{t}-\mathrm{i}}+\Sigma_{\mathrm{j}=1-12} \beta_{\mathrm{j}}\left|\operatorname{Ret}_{\mathrm{t}-\mathrm{j}}\right|$.

$\left|\operatorname{Ret}_{\mathrm{t}}\right|=\gamma_{0}+\Sigma_{\mathrm{I}=1-12} \gamma_{\mathrm{i}}\left|\operatorname{Ret}_{\mathrm{ti}}\right|+\Sigma_{\mathrm{j}=1-12} \delta_{\mathrm{j}} \operatorname{Vol}_{\mathrm{t}-\mathrm{j}}$

where $(\mathrm{Vol})$ is the turnover ratio, and $\left(\operatorname{Ret}_{\mathrm{t}}\right)$ is the natural logarithm of the month $\mathrm{t}$ price relative. The Granger causality test is in effect an F-test for block exogeneity, and as such is vulnerable to serial correlation (see, for example, Kennedy, 1993, p. 68). Therefore, before running the Granger causality tests, we correct the data series for first-order autocorrelation. Summary results of Eqs. (3) and (4) are shown in Table IV. The table provides the intercept and the first lag of the volume, and return variables along with an F-statistic for block exogeneity and the adjusted R-square statistic. In the bivariate case, the F-test for block exogeneity is equivalent to a test for Granger causality.

The results for Eq. (3) indicate that under a test of the null hypothesis that return does not Granger causing trading volume, the F-statistic is significant at the $1 \%$ level for 26 equities and at the 5\% level for 1 equity for a total of 27 of the 27 equities in the sample. None of the equity rejects the null hypothesis. Overall, these results constitute a strong evidence of returns causing trading volume. This means that the trading desire created by price changes is not immediately cleared. An explanation of such a finding is that most investors in the Russian markets are late in the informational queue and only trade some time after new information hit the market. This explanation is easily conceivable in most emerging markets where the state of their development might not allow spontaneous information dissemination. In general, the information arrival in these markets is likely to be sequential. Empirical research indicates that price adjustment to new information is "very quick". But according to Jennings and Barry (1983 and 1984), "very quick" can be interpreted as nearly instantaneous or as supporting gradual information dissemination. 
Smirlock and Starks (1984) find support for sequential over simultaneous information arrival. This is a puzzling finding as one might expect that because of the importance of these securities, the reaction to a price change expressed in terms of trading volume should be instantaneously. The fact is that, the effect persists after a week. This might be due to market frictions that keep all demands from instantaneously clearing. Whether the operational structure of the Russian Stock Exchange prevents investors to quickly react at new information arrival warrants further study of the structure of this market.

The results for Eq. (4) are very similar to those of Eq. (3). Again, the F-statistic is significant is highly significant at the $1 \%$ level for 22 ; at $5 \%$ level for 1 and at $10 \%$ for 2 equities for a total of 25 of the 27 stocks. Based on these results, again, our finding does not reject the null hypothesis that trading volume causes price change in the Russian equity market. This finding is quite different from the one presented by Saatcioglu and Starks (1998) at the index level. The results show that there is strong evidence of bi-directional causality on the basis of Granger-causality testing indicating that stock price changes adjust to lagged trading volume over one week trading time and that trading volume adjust to lagged price changes over the same time period.

\section{Table IV-A Granger causality test results}

This table provides summary results for a vector autoregression (VAR) analysis of the relation between price changes (returns) and volume for the twenty-seven Russian individual equities over the period January 1997 through December 2005 for a one lag period. The data series have been corrected for first-order autocorrelation before running the tests (t-statistics are in parentheses).

Eq (3) $V_{t}=\alpha+\beta_{1} V_{t-1}+\beta_{2}\left|\operatorname{Ln}\left(P_{t} / P_{t^{-1}}\right)\right|$

\begin{tabular}{|c|c|c|c|c|c|c|}
\hline Company & Observations & $\alpha$ & $\beta_{1}$ & $\mathbf{B}_{2}$ & F-statistic & A.R-square \\
\hline Aeroflot & 284 & $\begin{array}{c}671.451 \\
4.658\end{array}$ & $\begin{array}{l}0.512 \\
9.756\end{array}$ & $\begin{array}{c}0.053 \\
1.00\end{array}$ & 54.727 & 0.275 \\
\hline Severstal & 294 & $\begin{array}{c}115.680 \\
(6.795)\end{array}$ & $\begin{array}{c}0.429 \\
(8.072)\end{array}$ & $\begin{array}{c}0.115 \\
(2.160)\end{array}$ & 41.306 & 0.215 \\
\hline Unified Energy Sys. & 465 & $\begin{array}{c}54917.820 \\
(7.100)\end{array}$ & $\begin{array}{c}0.7180 \\
(20.895)\end{array}$ & $\begin{array}{c}-0.010 \\
(-0.299)\end{array}$ & 241.881 & 0.509 \\
\hline Sibirtelekom & 247 & $\begin{array}{c}5863.103 \\
(6.694)\end{array}$ & $\begin{array}{c}0.385 \\
(6.515)\end{array}$ & $\begin{array}{c}-0.002 \\
(-0.036)\end{array}$ & 21.349 & 0.141 \\
\hline Central Telecom & 219 & $\begin{array}{c}493.652 \\
(6.246)\end{array}$ & $\begin{array}{c}0.282 \\
(4.373)\end{array}$ & $\begin{array}{c}-0.138 \\
(-2.134)\end{array}$ & 13.053 & 0.099 \\
\hline Lenenergo & 203 & $\begin{array}{c}307.831 \\
(3.883)\end{array}$ & $\begin{array}{c}0.322 \\
(4.821)\end{array}$ & $\begin{array}{c}-0.023 \\
(-0.348)\end{array}$ & 11.688 & 0.095 \\
\hline Lukoil & 465 & $\begin{array}{c}387.002 \\
(387.002)\end{array}$ & $\begin{array}{c}0.778 \\
(0.778)\end{array}$ & $\begin{array}{c}-0.049 \\
(-0.490)\end{array}$ & 318.957 & 0.578 \\
\hline Mosonergo & 451 & $\begin{array}{c}25897.920 \\
(5.308)\end{array}$ & $\begin{array}{c}0.731 \\
(22.585)\end{array}$ & $\begin{array}{c}0.016 \\
(0.493)\end{array}$ & 261.327 & 0.536 \\
\hline Volga Telecom & 236 & $\begin{array}{l}102.363 \\
(8.184)\end{array}$ & $\begin{array}{c}0.298 \\
(4.806)\end{array}$ & $\begin{array}{c}-0.122 \\
(-1.964)\end{array}$ & 13.220 & 0.094 \\
\hline Purneftegaz & 183 & $\begin{array}{l}32.536 \\
(2.256)\end{array}$ & $\begin{array}{c}0.019 \\
(0.326)\end{array}$ & $\begin{array}{c}0.616 \\
(10.520)\end{array}$ & 55.661 & 0.374 \\
\hline Southern Telecom. & 287 & $\begin{array}{c}1418.816 \\
(6.004)\end{array}$ & $\begin{array}{c}0.289 \\
(5.077)\end{array}$ & $\begin{array}{c}0.018 \\
(0.324)\end{array}$ & 13.194 & 0.078 \\
\hline Rostelecom & 465 & $\begin{array}{c}1056.916 \\
(8.522)\end{array}$ & $\begin{array}{c}-0.075 \\
(-2.014)\end{array}$ & $\begin{array}{c}0.612 \\
(16.382)\end{array}$ & 134.252 & 0.036 \\
\hline Sberbank Of Russia & 428 & $\begin{array}{c}7.186 \\
(7.1970)\end{array}$ & $\begin{array}{c}0.522 \\
(12.450)\end{array}$ & $\begin{array}{c}0.010 \\
(0.234)\end{array}$ & 80.625 & 0.271 \\
\hline Surgutneftegas & 465 & $\begin{array}{c}13680.730 \\
(8.002)\end{array}$ & $\begin{array}{c}0.730 \\
(20.333)\end{array}$ & $\begin{array}{c}-0.064 \\
(-1.782)\end{array}$ & 231.351 & 0.498 \\
\hline North-W Telelecom & 271 & $\begin{array}{c}341.826 \\
(8.330)\end{array}$ & $\begin{array}{c}0.174 \\
(2.861)\end{array}$ & $\begin{array}{c}-0.105 \\
(-1.733)\end{array}$ & 4.871 & 0.028 \\
\hline Tatfneft & 447 & $\begin{array}{c}1580.382 \\
(5.289)\end{array}$ & $\begin{array}{c}0.695 \\
(20.156)\end{array}$ & $\begin{array}{c}0.028 \\
(0.811)\end{array}$ & 214.846 & 0.489 \\
\hline Uralsvyazinform & 322 & $\begin{array}{c}10560.690 \\
(6.954)\end{array}$ & $\begin{array}{c}0.477 \\
(9.720)\end{array}$ & $\begin{array}{c}-0.007 \\
(-0.145)\end{array}$ & 47.266 & 0.228 \\
\hline Yukos & 337 & $\begin{array}{c}811.788 \\
(6.860)\end{array}$ & $\begin{array}{c}0.451 \\
(9.231)\end{array}$ & $\begin{array}{c}-0.068 \\
(-1.394)\end{array}$ & 42.877 & 0.199 \\
\hline Gaz Auto Plt. & 268 & 5.872 & 0.408 & 0.011 & 26.875 & 0.162 \\
\hline
\end{tabular}




\begin{tabular}{|c|c|c|c|c|c|c|}
\hline & & $(5.669)$ & (7.166) & $(0.195)$ & & \\
\hline Irkutskenergo & 374 & $\begin{array}{c}2972.073 \\
(3.343)\end{array}$ & $\begin{array}{c}0.710 \\
(19.230)\end{array}$ & $\begin{array}{c}-0.013 \\
(-0.358)\end{array}$ & 187.410 & 0.499 \\
\hline Kamaz & 181 & $\begin{array}{c}239.561 \\
(3.812)\end{array}$ & $\begin{array}{c}0.147 \\
(1.951)\end{array}$ & $\begin{array}{l}-0.021 \\
(-0.274)\end{array}$ & 1.912 & 0.010 \\
\hline Kuzbassenergo & 159 & $\begin{array}{c}399.857 \\
(3.692)\end{array}$ & $\begin{array}{c}0.239 \\
(3.084)\end{array}$ & $\begin{array}{c}0.126 \\
(1.634)\end{array}$ & 7.042 & 0.071 \\
\hline Moscow City Tel. & 183 & $\begin{array}{c}6238.781 \\
(2.116)\end{array}$ & $\begin{array}{c}0.462 \\
(7.004)\end{array}$ & $\begin{array}{c}0.032 \\
(0.486)\end{array}$ & 24.572 & 0.205 \\
\hline Orbenburgneft Pf. & 196 & $\begin{array}{c}9.021 \\
(2.448)\end{array}$ & $\begin{array}{c}0.613 \\
(10.796)\end{array}$ & $\begin{array}{c}-0.016 \\
(-0.285)\end{array}$ & 58.299 & 0.369 \\
\hline Rostovenergo & 113 & $\begin{array}{c}2548.747 \\
(3.773)\end{array}$ & $\begin{array}{c}0.442 \\
(5.192)\end{array}$ & $\begin{array}{c}-0.27 \\
(-0.315)\end{array}$ & 13.578 & 0.182 \\
\hline Sakhalinmorneftegaz & 131 & $\begin{array}{l}26.216 \\
(3.076)\end{array}$ & $\begin{array}{c}0.514 \\
(6.787)\end{array}$ & $\begin{array}{c}0.024 \\
(0.314)\end{array}$ & 23.578 & 0.256 \\
\hline Samaraenergo & 161 & $\begin{array}{c}9873.728 \\
(1.754)\end{array}$ & $\begin{array}{c}-0.006 \\
(-0.075)\end{array}$ & $\begin{array}{c}-0.052 \\
(-0.660)\end{array}$ & 0.226 & -0.100 \\
\hline Slavneft Megionneftegz & 249 & $\begin{array}{l}42.112 \\
(2.778)\end{array}$ & $\begin{array}{c}0.654 \\
(13.535)\end{array}$ & $\begin{array}{c}0.015 \\
(0.304)\end{array}$ & 92.896 & 0.425 \\
\hline
\end{tabular}

\section{Table IV-B Granger causality test results}

This table provides summary results for a vector autoregression (VAR) analysis of the relation between price changes (returns) and volume for the twenty-seven Russian individual equities over the period January 1997 through December 2005 for a one lag period. The data series have been corrected for first-order autocorrelation before running the tests ( $t$-statistics are in parentheses)

$\mathrm{Eq}(4)\left|\Delta \mathrm{P}_{\mathrm{t}}\right|=\alpha+\beta_{1} \mid \operatorname{Lin}\left(\mathrm{P}_{\mathrm{t}-1} / \mathrm{P}_{\mathrm{t}-2} \mid+\beta_{2} \mathrm{~V}_{\mathrm{t}-1}\right.$

\begin{tabular}{|c|c|c|c|c|c|c|}
\hline Company & Observations & $\alpha$ & $\beta_{1}$ & $\beta_{2}$ & F-statistic & A.R-square \\
\hline Aeroflot & 338 & $\begin{array}{c}0.040 \\
(6.004)\end{array}$ & $\begin{array}{c}0.140 \\
(2.579)\end{array}$ & $\begin{array}{c}0.176 \\
(3.253)\end{array}$ & 11.060 & 0.056 \\
\hline Severstal & 322 & $\begin{array}{c}0.031 \\
(6.849)\end{array}$ & $\begin{array}{c}0.222 \\
(4.088)\end{array}$ & $\begin{array}{c}0.127 \\
(2.334)\end{array}$ & 12.719 & 0.068 \\
\hline Unified Energy Sys. & 466 & $\begin{array}{c}0.039 \\
(5.851)\end{array}$ & $\begin{array}{c}0.147 \\
(3.058)\end{array}$ & $\begin{array}{c}0.119 \\
(2.478)\end{array}$ & 11.437 & 0.043 \\
\hline Sibirtelekom & 296 & $\begin{array}{c}0.028 \\
(3.577)\end{array}$ & $\begin{array}{c}0.072 \\
(1.249)\end{array}$ & $\begin{array}{c}0.091 \\
(1.565)\end{array}$ & 2.124 & 0.008 \\
\hline Central Telecom & 277 & $\begin{array}{c}0.046 \\
(9.151)\end{array}$ & $\begin{array}{c}-0.121 \\
(-2.027)\end{array}$ & $\begin{array}{c}0.008 \\
(-0.125)\end{array}$ & 2.054 & 0.008 \\
\hline Lenenergo & 268 & $\begin{array}{c}0.044 \\
(6.510)\end{array}$ & $\begin{array}{c}0.048 \\
(0.798)\end{array}$ & $\begin{array}{c}0.171 \\
(2.831)\end{array}$ & 4.3100 & 0.024 \\
\hline Lukoil & 466 & $\begin{array}{c}0.033 \\
(8.599)\end{array}$ & $\begin{array}{c}0.073 \\
(1.549)\end{array}$ & $\begin{array}{c}0.293 \\
(6.239)\end{array}$ & 27.719 & 0.103 \\
\hline Mosonergo & 455 & $\begin{array}{c}0.056 \\
(6.606)\end{array}$ & $\begin{array}{c}0.032 \\
(0.690)\end{array}$ & $\begin{array}{c}0.119 \\
(2.534)\end{array}$ & 3.736 & 0.012 \\
\hline Volga Telecom & 287 & $\begin{array}{c}0.050 \\
(7.770)\end{array}$ & $\begin{array}{c}-0.078 \\
(-1.326)\end{array}$ & $\begin{array}{c}0.121 \\
(2.064)\end{array}$ & 3.041 & 0.014 \\
\hline Purneftegaz & 244 & $\begin{array}{c}0.042 \\
(7.624)\end{array}$ & $\begin{array}{c}0.150 \\
(2.387)\end{array}$ & $\begin{array}{c}0.142 \\
(2.256)\end{array}$ & 5.429 & 0.035 \\
\hline Southern Telecom & 338 & $\begin{array}{c}0.055 \\
(9.817)\end{array}$ & $\begin{array}{c}-0.023 \\
(-0.416)\end{array}$ & $\begin{array}{c}-0.010 \\
(-0.185)\end{array}$ & 0.107 & -0.005 \\
\hline Rostelecom & 466 & $\begin{array}{c}0.044 \\
(7.958)\end{array}$ & $\begin{array}{c}0.328 \\
(7.405)\end{array}$ & $\begin{array}{c}-0.018 \\
(-0.398)\end{array}$ & 27.660 & 0.103 \\
\hline Sberbank Of Russia & 435 & $\begin{array}{c}0.046 \\
(8.824)\end{array}$ & $\begin{array}{c}-0.041 \\
(-0.885)\end{array}$ & $\begin{array}{c}0.302 \\
(6.497)\end{array}$ & 21.121 & 0.085 \\
\hline Surgutneftegas & 466 & $\begin{array}{c}0.048 \\
(9.249)\end{array}$ & $\begin{array}{c}0.190 \\
(3.812)\end{array}$ & $\begin{array}{c}0.020 \\
(0.408)\end{array}$ & 9.532 & 0.035 \\
\hline North-West Telelecom & 330 & $\begin{array}{c}0.041 \\
(6.323)\end{array}$ & $\begin{array}{c}0.049 \\
(0.903)\end{array}$ & $\begin{array}{c}0.140 \\
(2.548)\end{array}$ & 3.890 & 0.170 \\
\hline Tatfneft & 456 & $\begin{array}{c}0.047 \\
(8.811)\end{array}$ & $\begin{array}{c}0.039 \\
(0.834)\end{array}$ & $\begin{array}{c}0.224 \\
(4.814)\end{array}$ & 13.272 & 0.051 \\
\hline Uralsvyazinform & 363 & $\begin{array}{c}0.036 \\
(3.981)\end{array}$ & $\begin{array}{c}0.011 \\
(0.221)\end{array}$ & $\begin{array}{c}0.217 \\
(4.226)\end{array}$ & 8.955 & 0.042 \\
\hline Yukos & 346 & 0.073 & -0.124 & 0.115 & 5.050 & 0.023 \\
\hline
\end{tabular}




\begin{tabular}{|c|c|c|c|c|c|c|}
\hline & & $(11.792)$ & $(-2.331)$ & $(2.163)$ & & \\
\hline Gaz Auto Plt. & 338 & $\begin{array}{c}0.045 \\
(5.676)\end{array}$ & $\begin{array}{c}0.014 \\
(0.268)\end{array}$ & $\begin{array}{c}0.299 \\
(5.672)\end{array}$ & 16.808 & 0.086 \\
\hline Irkutskenergo & 415 & $\begin{array}{c}0.048 \\
(7.649)\end{array}$ & $\begin{array}{c}0.080 \\
(1.641)\end{array}$ & $\begin{array}{c}0.179 \\
(3.694)\end{array}$ & 9.126 & 0.038 \\
\hline Kamaz & 267 & $\begin{array}{c}0.049 \\
(7.466)\end{array}$ & $\begin{array}{c}-0.022 \\
(-0.368)\end{array}$ & $\begin{array}{c}0.104 \\
(1.703)\end{array}$ & 1.497 & 0.004 \\
\hline Kuzbassenergo & 238 & $\begin{array}{c}0.050 \\
(5.775)\end{array}$ & $\begin{array}{c}0.074 \\
(1.132)\end{array}$ & $\begin{array}{c}0.085 \\
(1.309)\end{array}$ & 1.677 & 0.006 \\
\hline Moscow City Tel. & 267 & $\begin{array}{c}0.085 \\
(2.443)\end{array}$ & $\begin{array}{c}0.018 \\
(0.288)\end{array}$ & $\begin{array}{c}0.110 \\
(1.806)\end{array}$ & 1.664 & 0.005 \\
\hline Orbenburgneft Pf. & 239 & $\begin{array}{c}0.040 \\
(5.592)\end{array}$ & $\begin{array}{c}0.042 \\
(0.656)\end{array}$ & $\begin{array}{c}0.226 \\
(3.554)\end{array}$ & 6.926 & 0.047 \\
\hline Rostovenergo & 173 & $\begin{array}{c}0.061 \\
(3.493)\end{array}$ & $\begin{array}{c}0.142 \\
(1.881)\end{array}$ & $\begin{array}{c}-0.005 \\
(-0.690)\end{array}$ & 1.772 & 0.009 \\
\hline Sakhalinmorneftegaz & 200 & $\begin{array}{c}0.043 \\
(4.800)\end{array}$ & $\begin{array}{c}0.208 \\
(3.025)\end{array}$ & $\begin{array}{c}0.141 \\
(2.054)\end{array}$ & 6.964 & 0.056 \\
\hline Samaraenergo & 237 & $\begin{array}{c}0.062 \\
(5.562)\end{array}$ & $\begin{array}{c}0.094 \\
(1.450)\end{array}$ & $\begin{array}{c}0.122 \\
(1.886)\end{array}$ & 3.023 & 0.017 \\
\hline Slavneft Megionneftegz & 318 & $\begin{array}{c}0.062 \\
(7.249)\end{array}$ & $\begin{array}{c}0.033 \\
(0.588)\end{array}$ & $\begin{array}{c}-0.014 \\
(-0.242)\end{array}$ & 0.199 & -0.005 \\
\hline
\end{tabular}

\section{CONCLUSIONS}

Using weekly individual equity data on the Russian Stock Exchange, we show that there is strong evidence of bi-directional causality on the basis of Granger-causality testing indicating that stock price changes adjust to lagged trading volume over one week trading time and that trading volume adjust to lagged price changes over the same time period. This finding confirms the evidence reported by studies on many developed markets as the ones recently reported by by Moosa et al. (2003) and, Chen et al. (2004). However, the lack of strong evidence of the welldocumented positive absolute price-volume relationship may imply that differences in institutions and information flows in Russian Stock Markets are important enough to affect the valuation process of their equities. The information flow in these markets may well be disseminated sequentially instead of instantaneously as required in the Epps \& Epps model (1976). Consequently, investors who based their investment strategies on momentum, have to adjust their strategies when trading on Russian Stock Markets. However, whether the operational structure of the Russian Stock Exchange prevents investors to quickly react at new information arrival warrants further study of the structure of this market.

\section{REFERENCES}

1. Assogbavi, T., Khoury, N., and Yourougou, P., 1995. Short interest and the asymmetry of the price-volume relationship in the Canadian Stock market. Journal of Banking \& Finance 19 1341-1358

2. Assogbavi, T. Khoury, N. and Yourougou, P. La Causalité du Lien Volume-Prix de l'indice Toronto 35 Et Son Marché à Terme', Co-autored by Khoury and Yourougou, FINECO vol 2, sept. 1992, pp.55-65

3. Barry, C., Lockwood, L., 1995. New directions in research on emerging capital markets. Financial Markets, Instituti and Instruments 4, 15-36.

4. Bhagat, S., Bhatia. S.,1996. Trading Volume and Price Variability: Evidence on Lead-Lag Relations for Granger-Causality Tests. Wkg paper, U. of Colorado at Boulder.

5. Blume, L., Easley, D., O'Hara, M., 1994. Market statistics and technical analysis: the role of volume. Journal Finance 49 (1), 153-18 1.

6. Chan, W.S., Tse, Y.K., 1993. Price-volume relation in stocks: a multiple time series analysis on the Singapore market, Asia Pacific Journal of Management 10 (1), 39-56.

7. Chen, G., Firth, M., Xin, Y. 2004, The Price-Volume Relationship in China's Commodity Futures Markets. The Chinese Economy. Armonk, Vol. 37, Iss. 3; p. 87

8. Copeland, T.E., 1976. A model of asset trading under the assumption of sequential information arrival. Joumal of Finance 31, 1149-1168.

9. Crouch, R.L., 1970a. A nonlinear test of the random walk hypothesis. American Economic Review 60 (1), 199-202 
10. Crouch, R.L., 1970b. The volume of transactions and price changes on the New York Stock Exchange. Financial Analysts Journal 26 (4), 104-109.

11. Divecha, A.B., Drach, J., Stefek, D., 1992. Emerging markets: a quantitative perspective, Journal of Portfolio Management 19 (1), 41-50.

12. Epps, T.W., 1975. Security price changes and transaction volumes: theory and evidence. American Economic Review 65 (4), 586-597.

13. Epps, T.W., 1977. Security price changes and transaction volumes: some additional evidence. Journal of Financial Quantitative Analysis 12 (1), 141-146.

14. Epps, TW, Epps, M.L., 1976. The stochastic dependence of security price changes and transaction volume implications for the mixture-of-distributions hypothesis. Econometrica 44 (2), 305-321

15. Errunza. V.R., 1994. Emerging markets: some new concepts. Journal of Portfolio Management 20, 82-87,

16. Gallant, A.R., Rossi, P.E.. Tauchen, G.. 1992. Stock prices and volume. Review of Financial Studies 5 (2), 199-24'

17. Godfrey, M.D., Granger, C.W.J., Morgenstern, 0., 1964. The random-walk hypothesis of stock market behavior. Kyklos 17 (1), 1-30

18. Granger, CW.J., Morgenstern, 0., 1963. Spectral analysis of New York stock market prices. Kyklos 16 (1), $1-27$.

19. Harvey, C.R., 1995. Predictable risk and returns in emerging markets. Review of Financial Studies 8 (3), 773-816.

20. Hiemstra, C., Jones, J.D., 1995. Testing for linear and nonlinear Granger causality in the stock price-volume relationship. Journal of Finance 49, 1639-1664.

21. Jennings, R., Starks, L., Fellingham, J 1981. An equilibrium model of asset trading with sequential information arrival. Journal of Finance 36, 143-161

22. Jennings, Robert H., Barry, Christopher B. 1983. Information Dissemination and Portfolio Choice. Journal of Financial and Quantitative Analysis. Seattle:. Vol. 18, Iss. 1; p. 1 (19 pages)

23. Jennings, Robert H., Barry, Christopher B. 1984. Information Dissemination and Portfolio Choice. Journal of Financial and Quantitative Analysis. Seattle: Vol. 19, Iss. 4; p. 395 (8 pages)

24. Karpoff.J.M 1986, A Theory of Trading Volume. Journal of Financial, 41(5); p1069-1088

25. Karpoff, J.M., 1987. The relation between price changes and trading volume: a survey. Journal of Financial Quantitative Analysis 22 (1), 109-126.

26. Kennedy, P., 1993. A Guide to Econometrics, 3rd ed. MIT Press, Cambridge MA.

27. Moosa, I., Silvapulle, P., Silvapulle, M., 2003, Testing for temporal asymmetry in the price-volume relationship. Bulletin of Economic Research. Oxford. Vol. 55, Iss. 4; p. 373 (17 pages)

28. Rogalski, R.J., 1978. The dependence of prices and volume. Review of Economics and Statistics 60 (2), 268-274.

29. Saatcioglu, Kemal, Starks, Laura T. 1998. The stock price-volume relationship in emerging stock markets: The case of Latin America, International Journal of Forecasting. Amsterdam,Vol. 14, Iss. 2; p. 215 (11 pages)

30. Smirlock, M., Starks, L.T., 1985. A further examination of stock price changes and transactions volume. Journal of Financial Research 8 (3), 217-225.

31. Smirlock, M., Starks, L.T., 1988. An empirical analysis of the stock price-volume relationship. Journal of Banking Finance 12 (1), 31-4 1.

32. Tiao. G.C., Box, G.E.P., 1981. Modeling multiple time series with applications. Journal of the American Statis Association 76 (376), 802-816.

33. Tsc, Y.K.. 1991. Price and volume in the Tokyo stock exchange. In: Ziemba, W.T., Bailey, W., Hamao, Y. E Japanese Financial Market Research. North Holland, Amsterdam, pp. 91-119. 